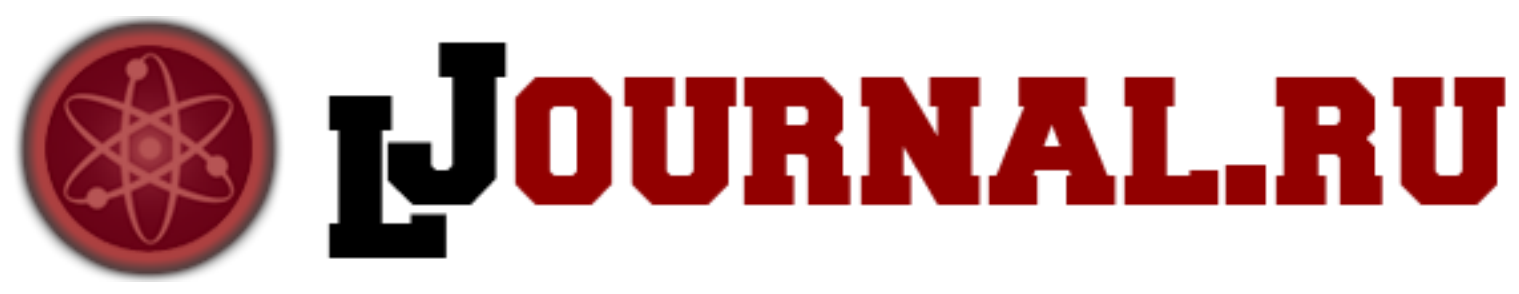

Ведерникова А.С., Коняшкин В. А., Гатилова А.В.

Томский Государственный Университет

Томск, Россия

doi: 10.18411/1j2016-1-02

\title{
Управление энергоёмкостью ВРП: проблемы и перспективы повышения энергоэффективности на примере Томской области
}

Формирование в России энергоэффективного общества - это неотъемлемая составляющая развития экономики России по инновационному пути. Энергосбережение и повышение энергоэффективности - один из основных источников будущего экономического роста. Однако до настоящего времени этот источник был задействован лишь в малой степени. Переход к энергоэффективному варианту развития должен быть совершен в ближайшие годы, иначе экономический рост будет сдерживаться из-за высоких цен и снижения доступности энергетических ресурсов.

Энергоемкость валового регионального или внутреннего продукта (ВВП, ВРП) - это зеркало экономического развития. Нехватка энергии может стать существенным фактором сдерживания экономического роста региона и страны. Динамика энергоёмкости ВРП Томской области за период 2007-2013 гг.

\begin{tabular}{|l|l|l|l|l|l|l|}
\hline Год & Потреблени & ВРП, & Энергоёмко & Энерго & Темп & Потреблен \\
& е первичной & млн. & сть ВРП, & ёмкост & изменен & ие энергии \\
& энергии, & рублей в & т.у.т./млн. & ь ВРП; & ия & на одного \\
& тыс. тонн & ценах & руб. в ценах & $\% ;$ \\
& у.т. & $2007 г$. & $2007 г$. & $\begin{array}{l}2007=1 \\
00 \%\end{array}$ & $\begin{array}{l}\text { мкости } \\
\text { ВРП в \% }\end{array}$ & т.у.т/челек \\
\hline 2007 & 7374395,921 & 214487,00 & 34381,55189 & 100 & - & 7208,15 \\
\hline 2008 & 8071734,357 & 248906,20 & 32428,82 & 94,3 & $-5,7$ & 7864,83 \\
\hline
\end{tabular}




\begin{tabular}{|l|l|l|l|l|l|l|}
\hline 2009 & 7260972,454 & 242481,20 & 29944,47592 & 87,1 & $-7,2$ & 7039,09 \\
\hline 2010 & 7606329,64 & 284292,00 & 26755,34183 & 77,8 & $-9,3$ & 7312,06 \\
\hline 2011 & 7238843,34 & 327014,15 & 22136,17799 & 64,3 & $-13,5$ & 6903,75 \\
\hline 2012 & 7597614,461 & 364693,09 & 20832,8993 & 60,6 & $-3,7$ & 7182,82 \\
\hline 2013 & 7700565,067 & 394736,50 & 19508,11508 & 56,7 & $-3,9$ & 7235,71 \\
\hline
\end{tabular}

В период 2007-2013 годов самое высокое энергопотребление зафиксировано в 2008 году. Снижение энергоемкости ВРП Томска в 2007-2013 годах (на 43 \%) имело место за счет структурных сдвигов экономики.

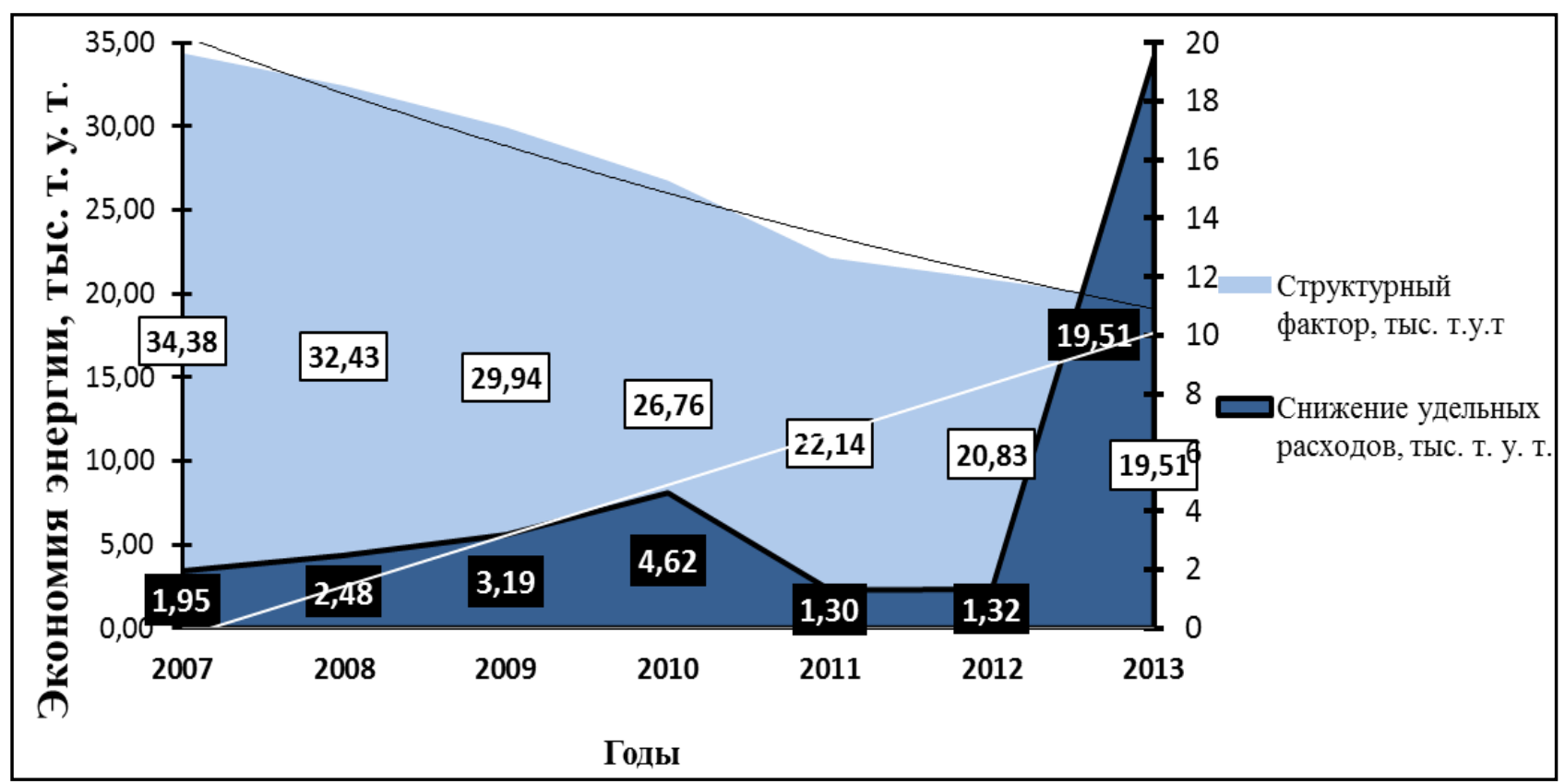

Экономия энергии за счёт снижения энергоёмкости ВРП

Таблица 3 Матрица SWOT-анализа факторов, влияющих на энергоёмкость и мероприятий по повышению энергоэффективности в Томской области.

\begin{tabular}{|l|l|l|}
\hline TО -Томская область & Сильные стороны & Слабые стороны \\
\cline { 2 - 3 } ЭЭ-энергетическая & э. Университеты & 1. Неспособность перенести \\
эффективность & выпускают специалистов, & влияние инфляции. \\
ТЭР - тепло- & способных в дальнейшем & Механизмы внедрены, но \\
энергетические & решить проблему. & используются \\
ресурсы & 2. ТО расположена на & неэффективно. \\
НДТ- наилучшие & территории, богатой & 2. Плохая мотивация или её \\
доступные & разными видами & отсутствие. \\
технологии & энергоресурсов, которые & 3. Недофинансирование. \\
ВИЭ- & можно извлечь (торф и & 4. Цели программ по \\
возобновляемые & т.д.) & повышению \\
источники энергии & 3. Повышение & энергоэффективности \\
\hline
\end{tabular}




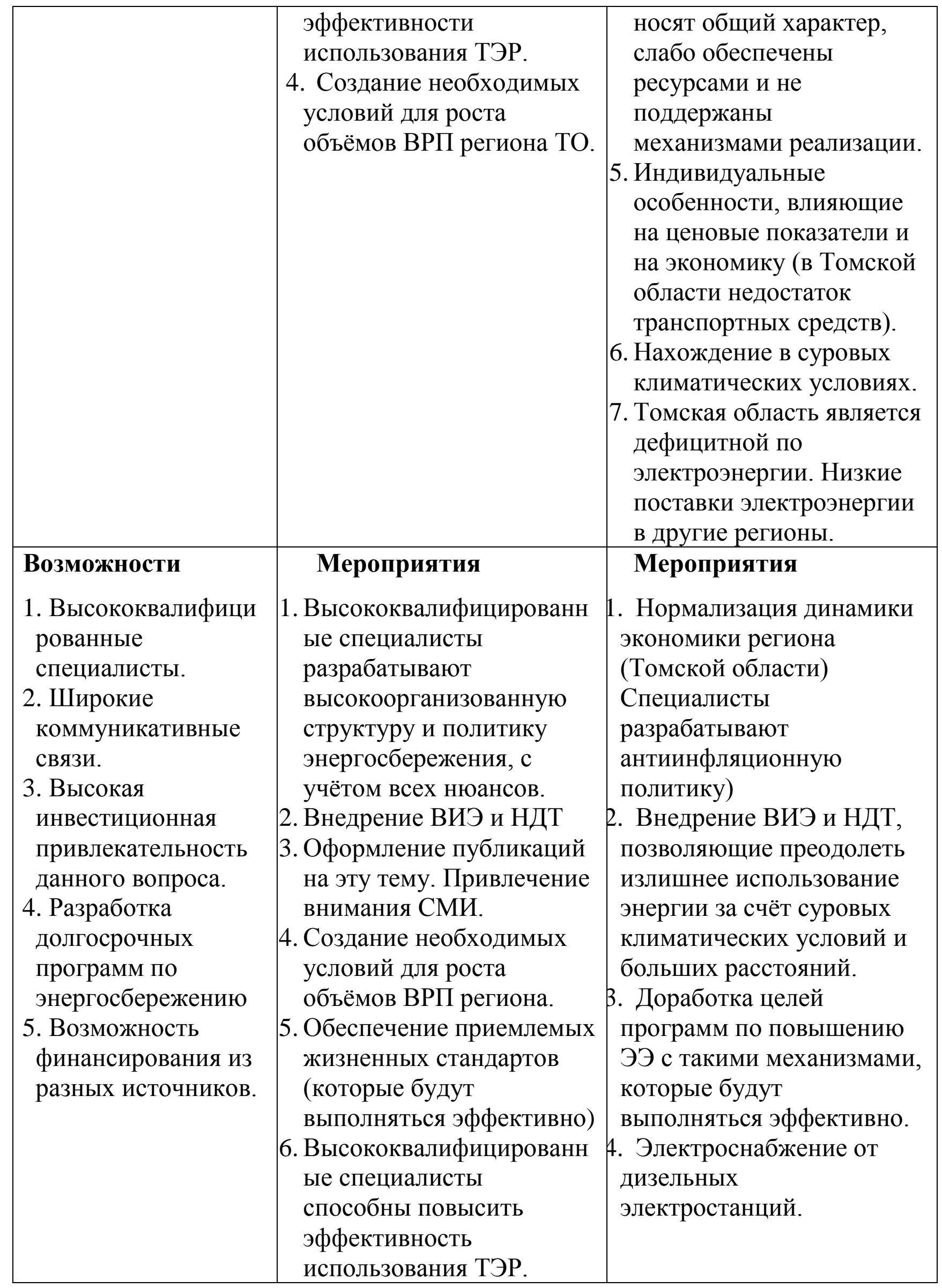




\begin{tabular}{|c|c|c|}
\hline $\begin{array}{l}\text { Угрозы } \\
\text { 1. Инфляция. } \\
\text { 2. Энергозатратные } \\
\text { перевозки сырья, } \\
\text { находящимся на } \\
\text { большом } \\
\text { расстоянии друг от } \\
\text { друга } \\
\text { предприятиям } \\
\text { 3. ЭЭ всей России } \\
\text { ниже, чем в других } \\
\text { странах, влияет на } \\
\text { область. } \\
\text { 4. Неэффективность } \\
\text { механизмов } \\
\text { саморегулирования } \\
\text { экономики. } \\
\text { 5. Форс-мажорные } \\
\text { ситуации } \\
\text { глобального } \\
\text { уровня, влияющие } \\
\text { на экономику } \\
\text { области. } \\
\text { 6. Несоответствия в } \\
\text { статистических } \\
\text { данных и } \\
\text { недоступность } \\
\text { информации. }\end{array}$ & $\begin{array}{l}\text { 1. Молодые специалисты } \\
\text { способны уберечь или } \\
\text { снизить риск угроз. } \\
\text { 2. Нормализация динамики } \\
\text { экономики. } \\
\text { 3. Изменение } \\
\text { производственных } \\
\text { мощностей для } \\
\text { повышения } \\
\text { производительности } \\
\text { предприятий } \\
\text { 4. Повышение потенциала } \\
\text { энергосбережения } \\
\text { области } \\
\text { 5. Мониторинг } \\
\text { экономических } \\
\text { изменений и построение } \\
\text { стратегических целей по } \\
\text { снижению энергоёмкости } \\
\text { ВРП области. } \\
\text { 6. Предотвращение } \\
\text { нестыковок по срокам } \\
\text { реализации программ из- } \\
\text { за сложности учёта } \\
\text { энергопотребления ТЭР. } \\
\text { 7. Обеспечение свободного } \\
\text { доступа к информации о } \\
\text { потреблении ТЭР для } \\
\text { быстрого проведения } \\
\text { всех расчётов. }\end{array}$ & $\begin{array}{l}\text { 1. Создание } \\
\text { высокоорганизованной } \\
\text { структуры и политики } \\
\text { энергосбережения с } \\
\text { учётом всех нюансов. } \\
\text { 2. Антиинфляционная } \\
\text { политика } \\
\text { 2.1. Анализ текущего } \\
\text { состояния экономики } \\
\text { региона и динамики. } \\
\text { 2.2. Разработка и введение } \\
\text { антиинфляционной } \\
\text { политики региона } \\
\text { 2.3.Перераспределение } \\
\text { финансовых потоков } \\
\text { региона для снижения } \\
\text { экономического } \\
\text { дисбаланса региона. } \\
\text { 3. Пропаганда } \\
\text { энергосбережения. } \\
\text { 4. Мониторинг } \\
\text { экономических } \\
\text { изменений, а также } \\
\text { построение } \\
\text { стратегических целей по } \\
\text { снижению энергоёмкости } \\
\text { ВРП области. }\end{array}$ \\
\hline
\end{tabular}

Матрица SWOT-анализа показывает, что спектр факторов и проблем, влияющих на энергоёмкость очень широк по типу и масштабу воздействия, и позволяет выделить пути решения проблем и определить мероприятия.

Главной целью региональной политики повышения энергоэффективности должно стать снижение энергоемкости ВРП, что может быть осуществлено на основе многоуровневой системы индикаторов, охватывающих все сектора потребления энергии. Дальнейшее развитие экономики Сибири невозможно без значительного повышения энергоэффективности производства. 


\section{Литература:}

1. Кокшаров В.А. "Комплексная методика анализа энергоёмкости валового регионального продукта” Вестник УРФУ. Серия “Экономика и управление” № 2/2014.

2. Государственная целевая программа “ Энергосбережение и повышение энергоэффективности Томской области на перспективу до 2020 года"

3. Статистические данные Росстата и Администрации Томской области о потреблении топливно-энергетических ресурсов за период 2007-2013 годы.

4. Суслов Н.И. Доклад “Повышение Энергоэффективности Экономики Сибири: роль ТЭК и цен на энергоресурсы" Институт Экономики и организации промышленного производства СО РАН, Новосибирск, 2011 г.

5. Климова Г.Н. "Роль топливно-энергетического баланса в программе энергетической эффективности Томской области" Известия Томского политехнического университета. 2005. Т. 308. № 7.

6. Информационно-Аналитическая Система "Мониторинг” Департамента государственной службы, кадров и мобилизационной подготовки Министерства образования и науки Российской Федерации [Интернетpecypc]: https://is-mon.ru/pages/socialenergy 